\title{
The Effect of Memorizing the Al Quran on Quality of Life in Stroke Patients With Aphasia Motoric Disorders
}

\author{
Ibnu Jafar Ma'ruf ${ }^{1}$, Os Hartanto ${ }^{2}$, Suminah $^{3}$ \& Endang Sutisna Sulaeman ${ }^{4}$ \\ ${ }^{1}$ Doctoral Candidate for Community Development and Empowerment Counseling, Main Interest in Health \\ Promotion, Sebelas Maret University, Surakarta, Indonesia \\ ${ }^{2}$ Department of Neurology Dr. Moewardi Hospital/ Faculty of Medical, Sebelas Maret University, Surakarta, \\ Indonesia \\ ${ }^{3}$ Department of Agricultural Counseling and Communication, Faculty of Agriculture, Sebelas Maret University, \\ Surakarta, Indonesia \\ ${ }^{4}$ Department of Public Health, Faculty of Medical, Sebelas Maret University, Surakarta, Indonesia \\ Correspondence: Ibnu Jafar Ma'ruf, Doctoral Candidate for Community Development and Empowerment \\ Counseling, Main Interest in Health Promotion, Sebelas Maret University, Surakarta, Indonesia. Tel: \\ 62-81-391-031-297. E-mail: jafarmedika@yahoo.co.id
}

Received: April 4, 2019 Accepted: May 2, 2019 Online Published: June 2, 2019

doi:10.5539/gjhs.v11n7p29 URL: https://doi.org/10.5539/gjhs.v11n7p29

\begin{abstract}
Background/aim: The purpose of this study was to determine and analyze the effect of memorizing the Al Quran surah Thaha verse 25-28 on functional communication skills, independence, and quality of life in stroke patients with motoric aphasia disorders.
\end{abstract}

Materials and Methods: The study was conducted at Ja'far Medika Karanganyar General Hospital, Central Java, Indonesia for approximately 3 months, with a total sample of 102 motor aphasia stroke sufferers, divided into 2 groups $(n=51)$ as controls receiving medical therapy, $(n=51)$ intervention group who received medical therapy and were trained to memorizing the Al Quran. The time of the study was carried out for three months starting December 4, 2017 to Maret 21, 2018. Type of quantitative research, using experimental design, simple randomized the pretest-posttest control group design.

Results: Based on the results of path analysis that memorizing the Al Quran significantly influences the quality of life in stroke patients with motoric aphasia disorders of $(r=0.735 ; \mathrm{p}=0.000)$, while family support is $(\mathrm{r}=0.321 ; \mathrm{p}$ $=0,000)$, functional communication is $(\mathrm{r}=0.017 ; \mathrm{p}=0.618)$ and independence by $(\mathrm{r}=0.035 ; \mathrm{p}=0.305)$. Thus the direct influence of memorizing the Al Quran and family support for the quality of life is better, without having to go through functional communication and the level of independence as mediation.

Conclusion: Memorizing the Al Quran surah Thaha verse 25-28 is very effective for improving functional communication skills, independence, and quality of life in stroke patients with aphasia motoric disorders.

Keywords: stroke, functional communication, family support, independence, quality of life

\section{Introduction}

The incidence of stroke ranks third as a cause of death after heart disease and cancer. Data from the American Heart Association/American Stroke Association (AHA/ASA) in Heart Disease and Stroke Statistics-2017 Updates, states that in America every 40 seconds an individual experiences a stroke and every 4 minutes someone dies from a stroke (Roger et al., 2017). Stroke is the third leading cause of death in developed countries, where 10 to $12 \%$ of all deaths are caused by strokes with a crude mortality rate of 50 to 100/100 thousand patients (Douiri et al., 2013). According to the basic health research of the Ministry of Health of the Republic of Indonesia (Riskesdas 2018), the prevalence of stroke increased when compared to the 2013 Riskesdas, the prevalence of stroke rose from $7 \%$ to $10.9 \%$ (Riskesdas 2018). Stroke will result in several effects including: 80\% partial or total reduction in arm and leg movements, $80-90 \%$ problem in thinking and remembering, 70\% suffering from depression, and 30\% having difficulty speaking (aphasia), swallowing, right and left differentiation (WHO, 2016).

Health problems that arise due to stroke vary widely, depending on the area of the brain that experiences infarction 
or death of the tissue and the affected location (Rasyid \& Lyna, 2007). One symptom of stroke is aphasia, which is the loss of speech function, including interference in writing, communication, reading, listening and understanding language. Stroke is a common cause of aphasia and is estimated to be around $25 \%-40 \%$ of stroke patients develop aphasia. During this time the handling of stroke with all its methods has not produced results as expected. Western medicine until now has not been able to cope well and perfectly, especially for stroke patients with motoric aphasia. To overcome this crucial problem, a stroke prevention strategy is needed which includes proper promotion, preventive, curative and rehabilitation aspects. Through memorizing the Al Quran that is repeated is expected to improve the quality of life of stroke patients. Recurring memorizing the Al Quran will be recorded in memory in the subconscious brain that sends signals to the conscious brain, can increase brain flexibility that can improve the brain (neuro plasticity) after experiencing a disorder (Huttenlocher, 2002). Memorizing the Quran regularly will cause neuroplasticity, which is the brain's ability to reorganize in the form of interconnections between brain nerves. Brain neural reorganization is influenced by stimulation, experience and the environment. Based on this concept, if there is damage to the part of the brain it is possible to experience recovery. This is in accordance with Murphy et al. (2009)'s research.

The Zulkurnaini et al. (2012) study shows that reading dhikr and verses of the Al Quran can increase Delta waves in the brain, shown in the Brodmann 8 area, where this area belongs to Broca's area which is responsible for processing semantic aspects of language and verbal fluency. According to Knyazev (2011) Delta wave activation contributes to the production of human growth hormone, human growth hormone (HGH) as a result of stimulation of the pituitary gland during activation of Delta waves. In addition, Delta waves also stimulate the release of anti-aging hormones such as dehydroepiandrosterone (DHEA) and melatonin, so memorizing repeated Al Quran is expected to also have an impact on improving functional communication in stroke patients with aphasia motor disorders. In general memorizing and listening to the Al Quran can improve mental health (Mahjoob et al., 2016; Fathilkamal et al., 2011; Eskandari et al., 2012; Bechir et al., 2017; Babamohamadi et al., 2015; Azis et al., 2015; Ashikin et al., 2012).

\section{Materials and Methods}

\subsection{Instrument}

(1) Aphasia screening observation sheet using the Frenchay Aphasia Screening Test (FAST) to determine the type of aphasia, namely motoric, sensory or global aphasia. (2) Questionnaire on functional communication skills using Derby Functional Communication Scale (DFCS). Used to measure the development and progress of functional communication skills of stroke patients. (3) Family support is a support system given to families towards family members which includes information support, instrumentation, emotional support and appreciation. (4) Barthel Index was used to assess the level of independence (Activities of Daily Living/ADL). The Barthel index was a very simple, easy to work measuring tool and is useful for evaluating patient dependence, which is related to ADL (Nakao et al., 2010; Sörbo, 2010). (5) The WHOQoL dimension was used to assess quality of life in stroke patients with motor affective disorders. The dimensions measured in WHOQoL cover 5 dimensions, namely physical health, psychological health, social relations, environment and spiritual well-being.

The study was conducted at Ja'far Medika Karanganyar General Hospital, Central Java, Indonesia for approximately 3 months, with a total sample of 102 motoric aphasia stroke sufferers, as evidenced by the results of head CT scan, divided into 2 groups $(\mathrm{n}=51)$ as controls receiving medical therapy, $(\mathrm{n}=51)$ intervention group who received medical therapy and were trained to memorizing the Al Quran. The time of the study was carried out for three months starting December 4, 2017 to Maret 21, 2018. Type of quantitative research, using experimental design, simple randomized the pretest-posttest control group design.

\subsection{Inclusion Criteria}

The sample inclusion criteria are as follows: (1) All stroke patients both bleeding and non-bleeding strokes that have been proven by CT scan of the head. And diagnosed clinically by a radiologist with a lesion abnormality in the left hemisphere. (2) Patients diagnosed with bleeding and non-bleeding strokes who experience motoric aphasia which routinely control for at least three months. Determination of motoric aphasia is based on the format of Frenchay Aphasia Screening Test (FAST), which is characterized by the inability of sufferers to coordinate or compile thoughts, feelings and wishes to be symbols that are meaningful and understood by others, but sufferers still have good understanding. (3) All stroke sufferers who are Muslim, both male and female, used to pray 5 times and without age restrictions. (4) Compostment awareness is normal awareness, fully aware, can answer all questions about the surroundings. (5) Patients with stroke who are awaited by their families and involved in communication exercises. (6) Patients and families are willing to become respondents. 


\subsection{Exclusion Criteria}

Exclusion criteria are conditions that cause the subject to meet the inclusion criteria but cannot be included in the study. Exclusion criteria in this study were: (1) Patients with stroke both bleeding and non-bleeding with abnormalities in multiple lesions in the left and right hemispheres which were shown from the results of a head CT scan diagnosed clinically by a radiologist. (2) Patients with disturbance of verbal communication before a stroke. (3) Patients who have a history of depression before stroke. (4) Patients who get anti-depression therapy. (5) Increased intracranial pressure (projectile vomiting, dizziness, unstable blood pressure, decreased consciousness). (6) Patients with stroke like syndrome are strokes caused not by blockage or bleeding, but due to other factors, most often for example intra-cranial tumors or intra-cranial infections as indicated by the results of CT scan or MRI of the head by a radiologist

\subsection{Dropout Criteria}

(1) Stroke patients who die before 3 months at the time of the study. (2) Patients do not control the Ja'far Medika General Hospital Karanganyar Central Java, Indonesia and after a home visit turns out the address does not match or change address and cannot be tracked. (3) Patients have recurrent stroke attacks within the first 3 months before the study is complete.

\subsection{Statistical Analysis}

This study was a quantitative study, using an experimental design, simple randomized design of the pretest-posttest control group. Data analyzed with the Statistical Package for Social Science version 23 (SSPS Inc., Chicago, IL, USA). The data obtained were then tested first with homogeneity test (univariate test), this test aims to determine the basic subject matter of the research between the intervention groups given medical and memorizing Al Quran therapy and the control group that only received medical therapy. The second was carried out bivariate test explaining the effect of one independent variable on one dependent variable, with a confidence level of $95 \%$ (p value $=0.05)$. The third was carried out path analysis with the aim to determine the direct and indirect influence between giving $\mathrm{Al}$ Quran memorization intervention and family support to functional communication skills, level of independence and quality of life in stroke patients with aphasia motoric disorders.

\section{Results}

\subsection{Characteristics Research Subject}

This study was conducted on 102 stroke patients in both bleeding and non-bleeding strokes that have been proven by head CT scan. And diagnosed clinically by radiologists with impaired lesions in the left hemisphere, patients were divided into 2 groups, the control group only received medical therapy and the intervention group received medical therapy in addition to memorizing the Al Quran surat Thaha verse 25 to 28.

Table 1. Characteristics of Research Subjects

\begin{tabular}{|c|c|c|c|c|}
\hline \multirow{2}{*}{\multicolumn{2}{|c|}{ Subjects Characteristics }} & \multicolumn{2}{|l|}{ Prosentage } & \multirow[b]{2}{*}{$\mathrm{P}$} \\
\hline & & Control group & Intervention group & \\
\hline \multirow{2}{*}{ Gender $^{\mathrm{a}}$} & Male & $25(49.0 \%)$ & $29(56.9 \%)$ & \multirow{2}{*}{0.427} \\
\hline & Female & $26(51.0 \%)$ & $22(43.1 \%)$ & \\
\hline $\mathrm{Age}^{\mathrm{c}}$ & & $57.75 \pm 10.95$ & $57.61 \pm 8.50$ & 0.944 \\
\hline \multirow{4}{*}{ Education $^{\mathrm{b}}$} & Elemntary School & $25(49.0 \%)$ & $31(60.8 \%)$ & \multirow{4}{*}{0.704} \\
\hline & Junior high School & $12(23.5 \%)$ & $3(5.9 \%)$ & \\
\hline & High School & $9(17.6 \%)$ & $8(15.7 \%)$ & \\
\hline & College & $5(9.8 \%)$ & $9(17.6 \%)$ & \\
\hline \multirow{4}{*}{ Income $^{b}$} & $0,5-1,5$ million & $25(49.0 \%)$ & $19(37.3 \%)$ & \multirow{4}{*}{0.173} \\
\hline & $1,6-2,5$ million & $23(45.1 \%)$ & $26(51.0 \%)$ & \\
\hline & $2,6-5$ million & $3(5.9 \%)$ & $6(11.8 \%)$ & \\
\hline & $>5$ million & $0(0.0 \%)$ & $0(0.0 \%)$ & \\
\hline
\end{tabular}




\begin{tabular}{|c|c|c|c|c|}
\hline \multirow{4}{*}{ Duration of stroke $\mathrm{e}^{\mathrm{b}}$} & $<1$ month & $26(51.0 \%)$ & $32(62.7 \%)$ & \multirow{4}{*}{0.287} \\
\hline & $>1-2$ month & $10(19.6 \%)$ & $7(13.7 \%)$ & \\
\hline & $>2-3$ month & $3(5.9 \%)$ & $2(3.9 \%)$ & \\
\hline & $>3$ month & $12(23.5 \%)$ & $10(19.6 \%)$ & \\
\hline \multirow{2}{*}{ Frequency of Stroke ${ }^{a}$} & 1 attack & $44(86.3 \%)$ & $42(82.4 \%)$ & \multirow{2}{*}{0.586} \\
\hline & $>1$ attacks & $7(13.7 \%)$ & $9(17.6 \%)$ & \\
\hline Family support $^{b}$ & & $63.10 \pm 6.14$ & $64.43 \pm 7.68$ & 0.057 \\
\hline
\end{tabular}

Note. a Chi Sqaure Test (nominal categorical data).

b The mann whitney test (ordinal or numerical categorical data is not normally distributed).

$\mathrm{c}$ Independent test $\mathrm{t}$ test (numerical data is normally distributed).

Based on the table above, it can be concluded that karcathics of research subjects between intervention groups who were given Quran memorization training and control groups were not significantly different or could be said to be homogeneous because the value of $\mathrm{p}>0.05$.

3.2 Effect of Memorizing the Al Quran on Ability Functional Communication in Stroke Sufferers With Motoric Aphasia Disorder

Table 2. Differences in functionality of communication between the control group and the intervention group

\begin{tabular}{lllc}
\hline \multirow{2}{*}{ Functional Communication (FC) } & Group & \multicolumn{2}{c}{$\mathrm{p}^{\mathrm{a}}$} \\
\cline { 2 - 3 } & Control & Interventional & 0.704 \\
\hline Week I (FC 1) & $7.20 \pm 3.79$ & $7.47 \pm 3.62$ & 0.026 \\
Week III (FC 2) & $9.39 \pm 2.45$ & $10.45 \pm 2.41$ & $<0.001$ \\
Week VI (FC 3) & $11.82 \pm 1.74$ & $13.53 \pm 2.43$ & $<0.001$ \\
Week IX (FC 4) & $14.24 \pm 1.88$ & $16.18 \pm 2.25$ & $<0.001$ \\
Week XII (FC 5) & $17.16 \pm 1.80$ & $19.35 \pm 2.27$ & \\
\hline
\end{tabular}

Note. ${ }^{\mathrm{a}}$ Mann whitney test (unpaired test for numeric data is not normally distributed).

Based on Table 2 in the control group, it is known that the functional communication ability on the first week averages at $7.20+3.79$, then at week 3 functional communication skills increase, to $9.39+2.45$, at week 6 the functional ability of communication increases, to $11.82+1.74$, in the 9th week functional communication capabilities increased, to $14.24+1.88$, and at week 12 , functional communication capabilities increased, to 17.16 +1.80 . The results of the difference test increase in the control group obtained a value of $p=0,000(p<0.05)$ which means that there is a significant change in functional communication skills in the control group.

In the treatment group it was known that functional communication skills at the first week's assessment, the average was $7.47+3.62$, at week 3 functional communication skills increased to $10.45+2.41$, at week 6 , functional communication skills increased to $13.53+2.43$, at week 9 , functional communication capability increases to $16.18+2.25$, and at week 12 , functional communication capabilities increase on average to $19.35+$ 2.27. The results of the different test increases in the intervention group obtained a value of $p=0,000(p<0.05)$ which means that there is a significant change in functional communication skills in stroke patients with aphasia motor disorders. 


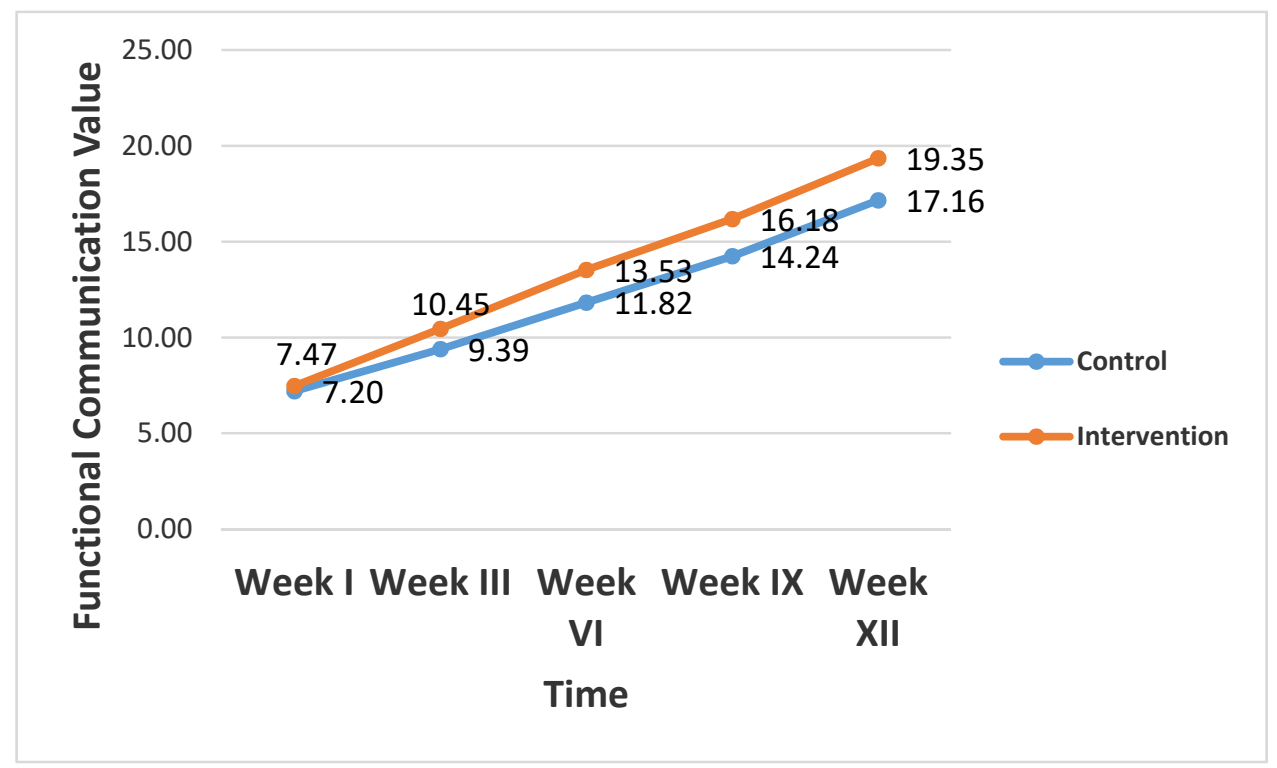

Figure 1. Comparative line diagram of functional communication capabilities between control groups and intervention groups

Based on Table 2 and Figure 1 it was known that the increase in functional ability of the intervesia group has improved better than the control group which is known at first week (FC1) does not show a significant difference $(\mathrm{p}=0.704)$, starting from the third week to twelfth week shows significant $(\mathrm{p}<0.05)$, thus giving the Al Quran memorization training intervention effective in improving the functional communication skills of stroke patients with motoric aphasia disorder. Table 2 and Fig. 1 also showed that the increase in functional ability of the intervesia group has improved better than the control group which is known at first week does not show a significant difference $(p=0.704)$, starting from the second to twelfth week shows significant $(p<0.05)$, thus giving the $\mathrm{Al}$ Quran memorization training intervention effective in improving the functional communication skills of stroke patients with motoric aphasia disorder

\subsection{Effect of Memorizing the Al Quran on Independence in Stroke Patients With Motoric Aphasia Disorder}

Table 3. Differences in independence between the control group and the intervention group

\begin{tabular}{llll}
\hline Independence (ADL) & \multicolumn{1}{l}{ Group } & \multicolumn{1}{c}{$\mathrm{p}^{\mathrm{a}}$} \\
\cline { 2 - 3 } & Control & Interventional & 0.463 \\
\hline Week I (ADL 1) & $39.71 \pm 18.59$ & $37.73 \pm 18.47$ & 0.109 \\
Week III (ADL 2) & $46.55 \pm 14.38$ & $50.88 \pm 12.41$ & 0.002 \\
Week VI (ADL 3) & $56.16 \pm 11.60$ & $62.39 \pm 9.70$ & $<0.001$ \\
Week IX (ADL 4) & $65.47 \pm 11.10$ & $74.75 \pm 9.78$ & $<0.001$ \\
Week XII (ADL 5) & $74.31 \pm 11.34$ & $85.04 \pm 10.35$ & \\
\hline
\end{tabular}

Note. ${ }^{a}$ Mann Whitney test (unpaired test for numeric data is not normally distributed).

Table 3 in the control group the level of independence at week 1 averaged $39.71 \pm 18.59$, the third week of independence increased on average to $46.55 \pm 14.38$, the 6 th week of independence increased to $56,16 \pm 11.60$, week 9 , independence increased to $65.47 \pm 11.10$, and the 12th week of independence increased to $74.31 \pm 11.34$. The results of different improvements in the control group obtained $p=0,000(p<0.05)$ which meant that there was a significant change in independence in the control group.

In the treatment group the level of independence of the 1 st week averaged $37.73 \pm 18.47$, at week 3 , independence increased to $50.88 \pm 12.41$, in the 6th week independence increased to $62.39 \pm 9,70$, week 9 , independence increased to $74.75 \pm 9.78$, and at week 12 , independence increased to $85.04 \pm 10.35$. The results of the level of 
independence in the intervention group obtained a value of $p=0,000(p<0.05)$ which means that there is a significant change in the level of independence in stroke patients with aphasia motoric disorders.

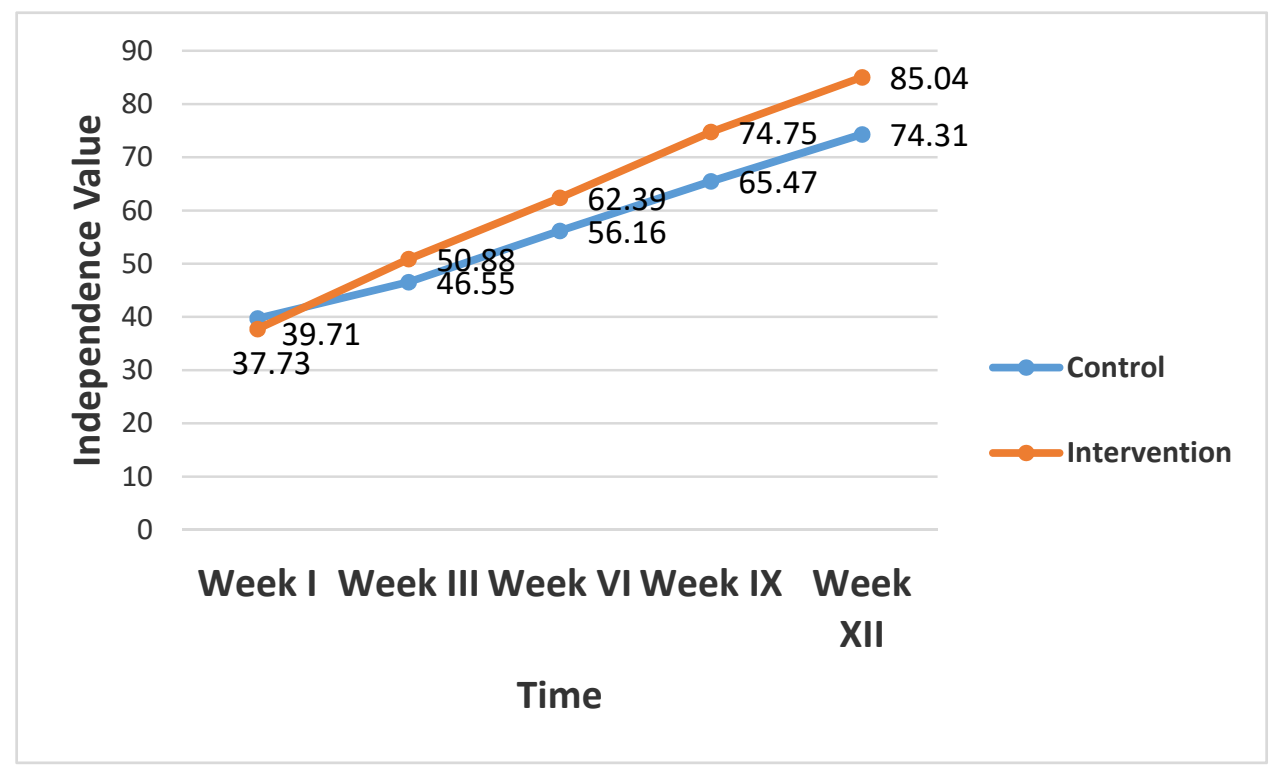

Figure 2. Comparative line diagram of independence between control groups and intervention groups

Table 3 and Figure 2 showed that the increase in the independence of the intervention group experienced a better increase compared to the control group where it was known that at the beginning the assessment at first week and third week did not show a significant difference $(p>0.05)$, starting at the sixth week until the twelfth week shows a significant difference $(\mathrm{p}<0.05)$, thus giving intervention to the Al Quran memorization exercise is effective in increasing the independence of stroke patients with motoric aphasia.

\subsection{Effect of Memorizing the Al Quran on Quality of Life in Stroke Sufferers With Motoric Aphasia Disorder}

Table 4. Differences in quality of life between control groups and intervention group

\begin{tabular}{llll}
\hline \multirow{2}{*}{ Quality of Life (QoL) } & \multicolumn{1}{l}{ Group } & \multirow{2}{*}{$\mathrm{p}^{\mathrm{a}}$} \\
\cline { 2 - 3 } & Control & Interventional & 0.691 \\
\hline Week I (QoL 1) & $37.10 \pm 11.21$ & $36.24 \pm 11.49$ & 0.001 \\
Week III (QoL 2) & $40.98 \pm 9.86$ & $48.75 \pm 13.43$ & $<0.001$ \\
Week VI (QoL 3) & $53.49 \pm 14.09$ & $68.16 \pm 17.74$ & $<0.001$ \\
Week IX (QoL 4) & $70.75 \pm 19.83$ & $88.43 \pm 19.42$ & $<0.001$ \\
Week XII (QoL 5) & $88.43 \pm 19.42$ & $102.24 \pm 14.48$ & \\
\hline
\end{tabular}

Note. ${ }^{a}$ Mann Whitney test (unpaired test for numeric data is not normally distributed)

Based on Table 4 in the control group it is known that based on questionnaire quality of life in the first week assessment (QoL 1) on average 37.10 \pm 11.21 , then in the third week assessment (QoL 2) questionnaire quality of life increased on average to $40.98 \pm 9.86$, in the assessment sixth week (QoL 3) questionnaire quality of life increased on average to $53.49 \pm 14.09$, in the ninth week assessment (QoL 4) questionnaire score of quality of life increased on average to $70.75 \pm 19.83$, and in the twelfth week assessment (QoL 5) questionnaire score quality of life increased on average to $88.43 \pm 19.42$. the results of different test increases in the control group obtained $\mathrm{p}=$ $0.000(\mathrm{p}<0.05)$ which means that there was a significant change in the quality of life in the control group

In the intervention group it was found that based on the quality of life questionnaire score at the first week assessment (QoL 1) an average of $36.24 \pm 11.49$, then in the third week assessment (QoL 2) the questionnaire 
quality of life improved on average to $48.75 \pm 13.43$, in the sixth assessment (QoL 3) questionnaire score of quality of life increased on average to $68.16 \pm 17.74$, in the ninth week assessment (QoL 4) questionnaire score of quality of life increased on average to $88.43 \pm 19.42$, and in the twelfth week assessment (QoL 5) questionnaire quality of life increased average becomes $102.24 \pm 14.48$. the results of different test improvement in the intervention group obtained $\mathrm{p}=0.000(\mathrm{p}<0.05)$ which means that there was a significant change in the quality of life in the intervention group.

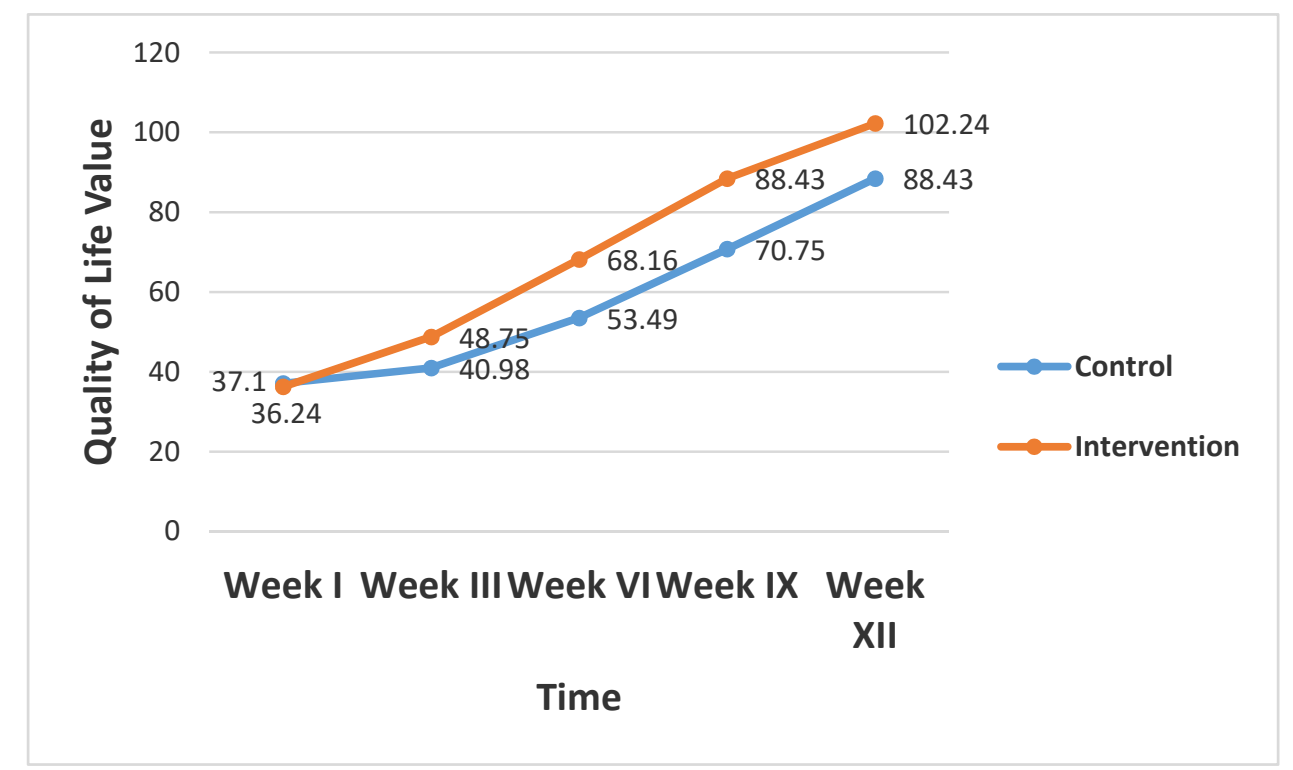

Figure 3. Line diagram of the comparison of Quality of Life between control groups and intervention groups

Based on Table 4 and Figure 3 it was known that the increase in functional ability of the intervention group experienced a better improvement compared to the control group where it was known at first week did not show a significant difference $(\mathrm{p}=0.691)$, starting from the third week to twelfth week shows the difference significant ( $\mathrm{p}$ $<0.05$ ), thus giving the Al Quran memorization training intervention effective in improving the quality of life of stroke patients with motoric aphasia disorder.

\subsection{Path Analysis}

Path analysis in this study was to find out whether there was a relationship between Al Quran memorization training and family support with functional communication, and the effect of functional communication on independence and the effect of independence on improving quality of life in stroke patients with motoric aphasia. 


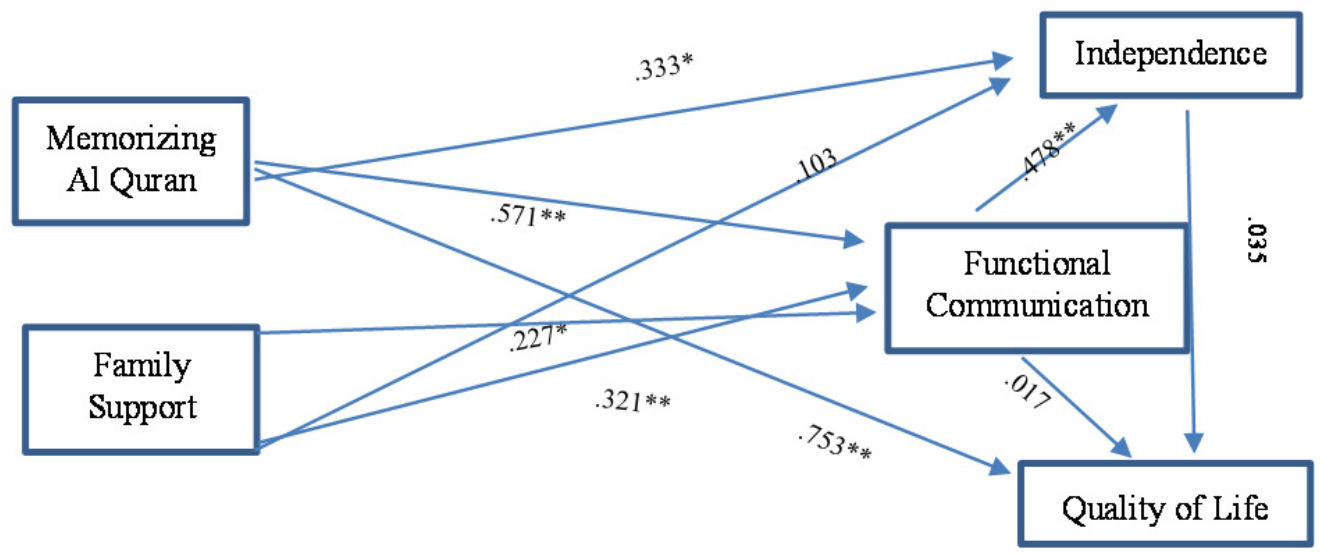

Description: $* * \mathrm{p}<0.001$

$* \mathrm{p}<0.05$

Figure 4. Pathway influence analysis of memorizing Al Quran and family support to quality of life with functional communication and independence as mediation

Based on Figure 4 can be described as follows: (1) The effect of Al Quran memorizing variables and family support on the improvement of combined functional communication both in stroke patients with motoric aphasia disorders get $r$ square $=0.579$ with $p=0.000(p<0.001)$ which means that the variable memorizing the Al Quran and support the family has an effect on the improvement of joint functional communication in stroke patients with moderate motoric aphasia. Or it can be said that $57.9 \%$ of the variance in functional communication is influenced by the variable memorizing the $\mathrm{Al}$ Quran and family support. (2) Partially it is known that the variable that has the greatest influence on improving functional communication in stroke patients with motoric aphasia is memorizing the Al Quran ( $\mathrm{r}=0.571 ; \mathrm{p}=0.000)$ compared to family support $(\mathrm{r}=0.227 ; \mathrm{p}=0.018)$. (3) The influence of Al Quran memorizing variables, family support and functional communication, on the combined independence of stroke patients with motoric aphasia disorders get the value of $r$ square $=0.679$ with $p=0.000(p<0.001)$ which means that the variable memorizing the Al Quran, support family and functional communication have an effect on the improvement of joint functional communication in stroke patients with strong levels of motoric aphasia. Or it can be said that $67.9 \%$ of the independence variance is influenced by the variable memorizing the Al Quran and family support and functional communication. (4) Partially functional communication variables $(r=0.478 ; \mathrm{p}=$ $0.000)$ have more influence on independence compared to memorizing the Al Quran $(r=0.333 ; p=0.009)$ and family support $(\mathrm{r}=0.103 ; \mathrm{p}=0.332)$ thus functional communication has the greatest influence on independence in stroke patients with motoric aphasia, while family support partially has no significant effect. (5) The effect of Al Quran memorizing variables, family support, improvement of functional communication and the level of independence of the combined quality of life in stroke patients with motoric aphasia disorders get $r$ square $=0.983$ with $p=0.000(p<0.001)$ which means that the variable memorizes Al Quran, family support, improvement of functional communication and level of independence affect the quality of life combined in stroke patients with motoric aphasia disorders with very strong levels. Or it can be said that $98.3 \%$ of the variance in quality of life is influenced by the variable memorizing the $\mathrm{Al}$ Quran, family support, improvement of functional communication and level of independence. (6) Partially it is known that the variable that has the greatest influence on the quality of life in stroke patients with motoric aphasia is memorizing the Al Quran $(\mathrm{r}=0.735 ; \mathrm{p}=0.000)$ compared to family support $(\mathrm{r}=0.321 ; \mathrm{p}=0.000)$, whereas functional communication $(\mathrm{r}=0.017 ; \mathrm{p}=0.618)$ and independence $(\mathrm{r}=$ $0.035 ; \mathrm{p}=0.305$ ) had no significant effect on quality of life. So based on the description, it can be seen that the direct effect of the variable memorizing the Al Quran and family support for the quality of life is better, without having to go through functional communication and independence as mediation.

\section{Discussion}

\subsection{Effect of Family Support on Stroke Patients}

Family support was a factor that affects the recovery of stroke patients in general, especially in patients who experience impaired verbal communication or motor aphasia. The attitude of the family was an important factor in helping sufferers of aphasia motor to overcome their disability. According to Bullian et al. (2007) the involvement of family members and friends in training can increase the effectiveness of rehabilitation. In addition the family 
environment was also a suitable environment to stimulate aphasia language skills, because the stimulation can be done informally, can choose the right time, when the patient is in a motivated state and family members know enough about the condition of the patient. With the accompaniment of the family the patient feels comfortable, calm and stronger in accepting his physical condition, so that it is expected to have a good impact on the healing process of the disease. The support provided in this study can cover four dimensions, namely information, emotional, appreciation and instrumental support related to the care of stroke patients with the Al Quran memorization method in stroke patients with motor aphasia.

\subsection{Effect of Al Quran Memorizing Exercise on Functional Communication Ability in Stroke Patients With Motor Aphasia Disorders}

Figure 1 and Table 1 shows that the increase in functional communication skills in the intervention group experienced a better improvement compared to the control group. At first functional communication (FC1) did not show a significant difference $(p=0.704)$, but at the second to fifth time showed a significant difference $(p<0.05)$, thus giving Al Quran memorization training intervention was effective in improving communication skills functional stroke sufferers with montoric aphasia.

Religious obedience, including reading and memorizing the Al Quran will lead to peace of mind, freedom from stress and can control anger through psychoneuroimmonology pathways (Syed, 2003; Tartaro et al., 2005). Based on the concept of psychoneuroimmunology, anxiety is a stressor that can reduce the body's immunity, this occurs through a series of actions mediated by the Hypothalamus-Pituatry-Adrenal (HPA-Axis), anxiety will also stimulate the hypothalamus to increase the production of Corticotropin Releasing Factor (CRF) to stimulate hormones pituitary anterior to increase the production of Adrenocorticotrofic hormone (ACTH) (Aghamohamadi et al., 2014; Steptoe et al., 2005; Nurdin, 2015; Tartaro, 2005). This hormone will stimulate the adrenal cortex to increase cortisol secretion, cortisol will further suppress the body's immune system (Guyton \& Hall, 2008). Psychoneuroimmunology is an integrated concept of immune-regulation functions to maintain homeostasis. To maintain homeostasis, the immune system integrates with the brain's psychophysiological process, and therefore influences and is influenced by the brain. Through the psychoneuroimonology approach, stroke patients who always read and memorize the Al Quran will affect brain tissue neuroplasticity. Namely the brain's ability to reorganize in the form of interconnections of the brain's nerves which are influenced by stimulation, experience and the environment. Based on this concept, if there is damage to the part of the brain it is possible to experience recovery. This is in accordance with Rahayu research (2012) and Murphy (2009) activation of the brain during post-stroke nerve regeneration is very important to support brain repair. Brain activation which consists of breathing exercise, brain harmonization exercise and memory brain exercise is given to get a relaxing effect that will stimulate the formation of substances that are important for nerve cell growth, and have an influence on brain structures such as the visual cortex, hippocampus and cerebral cortex, this is in accordance with the research Moller (2006). Furthermore the effects shown are improvements in global sensory, motor and cognitive functions. The brain will regenerate faster, so it will affect the improvement of the general condition of stroke patients with motor aphasia. Likewise it will affect functional communication skills, level of independence and quality of life. This was confirmed by Nurdin (2015) research that the mechanism of interaction between behavior, nervous system, endocrine system, and immune function. The behavioral component of this interaction involves Pavlov's conditioning in the increase and suppression of antibodies and cellular immune responses. This conditioner expresses as an effect of the experience of stress on immune function.

This theory says that learning languages is related to the formation of a relationship between stimulus-response activities and the strengthening process. This strengthening process is reinforced by a conditioned situation, which is done repeatedly. Memorizing the Al Quran is the best condition for remembering God, so that the heart and mind are at ease. As in Al Quran surah Ar-Ra'ad verse 28:

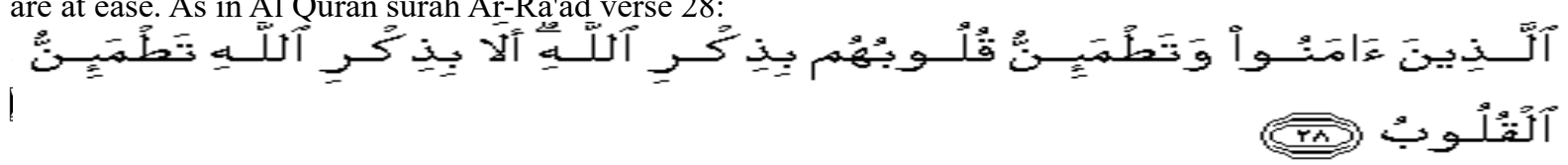

(That is) those who believe, and their hearts are ensured by the remembrance of Allah. Remember, only by remembering God is the heart satisfied (Surah Ar-Ra'ad [13]: 28).

A calm heart will affect the decrease in the production of the hormone cortisol (stress hormone) and increase the production of endorphins (immune hormones) so as to increase immunity (Sholeh, 2013; Almerud, 2003; Khatoni, 1997; Chang et al., 2008). In stroke patients who always repeat memorization of the Al Quran the level of immunity, the quality of life is getting better, and the risk of repeated attacks is getting smaller. 
The Dubuc (2004) study shows that reading the dzikir and verses of the Al Quran can increase Delta waves in the brain, shown in the Brodmann 8 area, where this area belongs to Broca's area which is responsible for processing semantic aspects of language and verbal fluency. Repeated memorization of the Al Quran will also have an impact on improving functional communication in stroke patients with motor aphasia. According to Mendoza (2013) delta wave activation contributes to the production of human growth hormone (HGH) as a result of stimulation of the pituitary gland during activation of delta waves. In addition, delta waves also stimulate the release of anti-aging hormones such as dehydroepiandrosterone (DHEA) and melatonin.

This is in accordance with the theory of Thorndike's law of exercise, that exercises that are always repeated will cause a stronger effect, namely the occurrence of strengthening the memory of what is always repeated, so it will affect strengthening at the level of functional communication, this memorization of stroke patients is more fluent and fluent so that it will have an impact on improving communication in general.

In Thorndike's theory of connectionism one can claim that practice can strengthen bonds, connections or relationships (Thorndike, 1932). Thorndike's theory introduces two aspects, namely the law of use and the law of disuse. Usability law is that if a relationship can be made between one situation and one response then the strength of the relationship in the situation that has that equation will increase. The more frequently used, repeated and tried, the stronger the relationship. Thorndike acknowledges that the magnitude of the relationship is influenced by various things such as power / strength and the length of time from the training period. So the more effort you make, both the costs, the energy and the time used to practice, the better the results will be. The law of uselessness is to follow the law of usability that is without training a relationship will be weak. In other words a relationship that can be changed between one situation and one response does not occur in the same situation, then the relationship will be weak. Factors to consider in exercise are the more frequent stroke sufferers repeat things, the more they remember the information provided. Providing repeated questions will improve their practice. So the more often memorizing the Al Quran and using it in dhikr, praying and being used for prayer recitations, the better, fluent and fluent, this will facilitate verbal communication skills in general in stroke patients with motor aphasia. So the theory of Thorndike's law of exercise is very appropriate to be used to train memorization of the Al Quran in stroke patients with aphasia motor disorders to improve functional communication skills well.

Pavlov's theory (Hergenhahn \& Olson, 1997) also plays a role in providing learning to memorize, learning in principle is to imitate or imitate the behavior of someone who provides training. The more often imitated, accustomed or imitated the utterance of memorizing the Al Quran, the more fluent and fluent his speech, this would also strengthen verbal communication skills in general. Good communication skills in stroke patients against other people, it will increase self-confidence to recover. With good functional communication skills, it is expected to increase the independence and quality of life.

\subsection{Effect of Al Quran Memorizing Exercises on Independence in Stroke Patients With Motorized Aphasia Disorders}

Based on Figure 2 and Table 2 it is known that the increase in the independence of the intervention group experienced a better improvement compared to the control group where it was known that at the beginning the assessment at the time of Independence first week (ADL 1) and Independence third week (ADL 2) did not show a significant difference $(p>0.05)$, starting at the third to fifth time showed a significant difference $(p<0.05)$.

Thus the provision of Al Quran memorization training interventions can effectively increase the independence of stroke patients with motor aphasia. The better the communication, the stroke sufferers are better at understanding each incident, so that communication with family, friends, or interlocutors is more fluent. This makes it easy to understand each incident, especially the health problems it suffers. In accordance with the theory of the Health Belief Model (HBM) (Sulaeman, 2013; Tang et al., 2002) that is the readiness of individuals to change their behavior in order to avoid a disease or risk to their health. Thus stroke sufferers have readiness to change their behavior better, for example taking regular medication, regular control, obeying doctor's recommendations, including changing lifestyle such as mindset, eating and activities, all in order to increase independence in daily life (Stephen et al., 2005). The level of independence is also due to family support, this is in accordance with the research Sit et al., 2004.

The level of independence of stroke patients can be assessed using the Barthel Index assessment which is often used in evaluating disability when patients are admitted to hospital and during treatment (Rasyid, 2007). Sarafino (2006) states that family support refers to assistance received by individuals from other people or groups around who make the recipient feel comfortable, loved and valued and can have a positive effect on him. Increasing available family support can be an important strategy in reducing or preventing mental stress and post-stroke depression (Salter, Foley, \& Teasell, 2010; Sooki et al., 2011). 
Bosworth (2009) further stated that family support greatly influences the mental health of family members. Physical conditions experienced by patients suffering from a stroke will result in patients not believing in themselves, feeling inadequate, meaningless and worthless, especially stroke patients with motor aphasia. In addition, the process of healing and rehabilitation in stroke can occur for a long time, so it requires family assistance in providing planning and providing planning aspects (Smeltzer \& Bare, 2002). What was seen during the research was that all respondents received real family support which can be seen directly when families always accompanied respondents to control, maintain and provide assistive devices in the form of wheelchairs, wolkers, tripods and communication devices.

Optimal family support can improve the health status of stroke patients in general, thus the level of independence is also getting better. In accordance with the study of Sit, Wong, Clinton, Li and Fong (2004) on the impact of social support on the health of home stroke patients by family care giver, it was found that giver family care in post-stroke patients could improve their ability to carry out daily living activities independently and get better with support and social support from the family that will improve the psychosocial health status of post-stroke patients. In this case, the family is the smallest social unit that is most closely related to the sufferer. Therefore, family support is needed by stroke patients as a support system that can support it in developing effective responses or coping to adapt to the stressors that they face related to their physical, psychological, social, environmental and spiritual health (IYW, 2005; Lasserman \& Perkins, 2001; Pouralkhas et al., 2012). With adequate family support, stroke patients can also maintain their health status. Thus, it is further known that family support can have a positive impact on improving the quality of life for stroke patients (Nirmal et al., 2008; Wig et al., 2006).

\subsection{Effect of Al Quran Memorizing Exercises on Quality of Life in Stroke Patients With Motor Aphasia Disorders}

Figure 3 and Table 3 shows that the increase in functional ability of the intervention group experienced a better improvement compared to the control group where it was known that initially the quality of life (QoL 1) did not show a significant difference $(\mathrm{p}=0.691)$, starting from the second to the fifth showed a significant difference ( $\mathrm{p}$ $<0.05$ ), thus giving an Al Quran memorization exercise intervention is effective in improving the quality of life of stroke patients with montoric aphasia. Quality of life is directly proportional to the level of independence, the more independent the life, the better the quality of life. Improving the quality of life in stroke patients because one of them is good family support, both information support, emotional support, instrumentation, and appreciation support. With optimal family support, both from family, friends or health workers, severe mental and emotional problems can be prevented, so stroke sufferers are more motivated to live independently and feel needed (Huang et al., 2010).

Living independently in stroke patients is shown in daily life, for example, can take their own medicine, both the time and dosage, as well as bathing, eating, changing clothes and going to the toilet can be done without the help of others. This is in accordance with the research conducted by Almborg (2010). By living independently, the quality of life is getting better. Good quality of life in stroke patients in terms of 5 aspects, namely physical, psychological, environmental, social relations and spiritual health. Physical health is shown to reduce pain, normal blood pressure is stable, blood sugar is normally controlled, blood cholesterol levels are getting better and the level of independence is getting better.

Improving psychological health in stroke patients is indicated by general mental health which was always increasing, reducing anxiety. worry and anxiety, always optimistic and confident, not easily angry, emotional and accepting his condition wholeheartedly (Kim, 2016; Miller et al., 2011 ). Increased psychological health in stroke patients with motoric aphasia disorders is also indicated by deep sleep. Deep sleep will produce optimal serotinin hormone, so the process of neurotransmitters is getting better, then the process of cell regeneration (neuro plastisity) in the brain gets better. Environmental health shows that stroke sufferers have an awareness and concern for the environment around their homes, for example being able to sweep, clean sewers, clean the grass around the house. Health social relations are demonstrated by friendship: being able to use social media services, attending to the invitation of neighbors who have work. Spiritual health is indicated by the increase in worship carried out, for example, five prayers in congregation to the mosque, a lot of dhikr, reading the Al Quran, attending recitations, listening to recitations via radio, youtube and carrying out other sunnah services.

Improving the quality of life in stroke patients with aphasia motoric disorder after being trained to memorize the $\mathrm{Al}$ Quran can also make the coping effect better, people who always remember Allah through memorizing the Al Quran will find their hearts calm, so that besides increasing immunity and reducing the effects of stress also increases the coping effect (Mohamed, 2010). Coping strategy is coping that is carried out consciously and directed in overcoming pain or facing a stressor. If coping is done effectively, the stressor no longer causes psychological stress, illness, or pain, but turns into a stimulant that stimulates achievement and good physical and 
mental condition.

The coping mechanism refers to both mental and behavioral, to master, tolerate, reduce, or minimize a stressful situation or event. Coping mechanism is a process in which individuals try to handle and master stressful situations that suppress the consequences of the problems they are facing by making cognitive and behavioral changes in order to gain a sense of security in themselves, according to Sholeh research (2004). Coping effect is Coping is a mechanism to overcome the changes faced or the burden received. If this coping mechanism is successful, a person will be able to adapt to the changes they face, be more resilient in accepting the test and accepting his condition as wholeheartedly.

It can be concluded that stroke patients who are coping well will easily solve the problem at hand. Besides good coping will also affect behavior changes and changes in organ tissue in stroke patients (Hughes et al., 2004). Keliat (1999) and Folkman \& Lazarus (1985) in their study stated that repair of organ tissue in stroke patients occurred before 6 months of occurrence. The results of the Kelly-Hayes et al. (2003) who said that 6 weeks after discharge planning in stroke patients had changes in physical, cognitive and emotional changes, depressive symptoms decreased, participation in social activities increased. Almborg (2010) conducted a study with results 2 to 3 weeks after discharge planning for depressive symptoms in decreased ischemic stroke patients and increased participation in social activities.

A good coping effect will affect repair of organ tissues, especially in the left hemisphere of the brain of stroke patients, while the left hemisphere is the center of language and communication. So that it will affect the improvement of verbal communication in general in stroke patients with aphasia motoric disorders. This language center makes humans able to communicate, interact and understand with their interlocutors.

This study is the first study that has assessed the effect of memorizing the Al Quran in stroke patients with motoric aphasia.The limitations of this study are the relatively small sample size, the short duration of the intervention, and the impossibility of assessing lifestyle factors, which might influence the results achieved. Thus, clinical trials with a larger sample size and longer duration of intervention are recommended.

\section{Conclusion}

Memorizing the $\mathrm{Al}$ Quran surah Thaha verse 25 to 28 , is an effective way to improve functional communication skills in stroke patients with aphasia motoric. Memorizing the Al Quran continuously with good family support will also increase the level of independence and quality of life. Shown by the increase in psychological and spiritual health aspects, namely stable emotions, not irritability, relaxed mind and increasing coping effects. Spiritual health is shown by increasing worship, in addition to performing obligatory worship as well as performing sunnah worship, praying five times in congregation to mosques, attending religious activities, often listening and seeing religious lectures, so that religious understanding also increases. That all will contribute to improving the quality of life of stroke patients with aphasia motoric disorders.

\section{Acknoledgements}

We would like to thank Yuni Ratna Dewi, MD and all staff of the Ja'far Medika Karanganyar General Hospital, Central Java, Indonesia for their contributions.

\section{Competing Interests Statement}

The authors declare that there are no competing or potential conflicts of interest.

\section{References}

Abdullah, A., \& Omar, Z. (2011). The effect of temporal EEG signals while listening to Quran recitation. International Journal on Advanced Science, Engineering \& Information Technology, 1(4), 372-375. https://doi.org/10.18517/ijaseit.1.4.77

Aghamohamadi, M., Nazar ali, P., \& Hanachi, P. (2014). The Effect of Voice of the Holy Quran on Cortisol, ACTH and Psychological Factors During one Maximal Exercise in Young Female Athletes. ZUMSJ, 22, 110-118.

American Stroke Association. Update to the AHA/ASA recommendations for the prevention of stroke in patients with stroke and transient ischemic attack. Stroke, 39, 1647-1652. https://doi.org/10.1161/STROKEAHA.107.189063

Alfano, K. M., \& Cimino, C. R. (2008). Alteration of Expected Hemispheric Assymetries: Valence and Arousal Effects in Neuropsychological Models of Emotion. Brain and Cognition, 66, 213-220. https://doi.org/10.1016/j.bandc.2007.08.002

Almborg. H. A. (2010). Discharge after stroke-importan factor for health. Realeted Quality of Life. Journal of 
clinical nursing, 19, 2196. https://doi.org/10.1111/j.1365-2702.2010.03251.x

Almerud, S., \& Petersson, K. (2003). Music therapy-a complementary treatment for mechanically ventilated intensive care patients. Intensive Crit Care Nurs., 19(1), 21-30. PubMed: 12590891. https://doi.org/10.1016/S0964-3397(02)00118-0

Andreas, E., Anders, M. F., Lars, T. W., Torgeir, M., Øyvind, S., Vivi, A. L., \& Kristine, B. W. (2010). Effects of Memory Training on Cortical Thicness in Elderly. Neuroimage. 52, 1667-1676. https://doi.org/10.1016/j.neuroimage.2010.05.041

Andri, S. M. (2008). Tatalaksana depresi pasca stroke. Tinjauan pustaka. Majalah Kedokteran Indonesia, 58(3), 81-85. https://doi.org/10.30812/matrik.v17i1.64

Ashikin, Z., Ros, S. S., Abdul, K., Zunairah, H. M., \& Roshakimah, M. I. (2012). The comparison between listening to Al-Dhikr \& Al-Quran and listening to classical music on the brainwave signal for the Alpha band. Paper presented at the 2012 Third International Conference on Intelligent Systems Modelling and Simulation, Kota Kinabalu, Malaysia. https://doi.org/10.1109/ISMS.2012.60

Arslan, S., Celebioglu, A., \& Tezel, A. (2009).'Depression and Hopelessness in Turkish Patients with Cancer Undergoing Chemotherapy. Japan Journal of Nursing Science, 6, 105-110. https://doi.org/10.1111/j.1742-7924.2009.00127.x

Avolio, B.J., Zhu, W., Koh, W., \& Bhatia, P. (2004). Transformational Leadership and Organizational Commitment: Mediating Role of Psychological Empowerment and Moderating Role of Structural Distance. Journal of Organizational Behavior, 25, 951-968. https://doi.org/10.1002/job.283

Azis, W., Nooryanto, M., \& Andarini, S. (2015). Terapi Murotal Al-Qur'an Surat Arrahman Meningkatkan Kadar $\beta$-Endorphin dan Menurunkan Intensitas Nyeri pada Ibu Bersalin Kala I Fase Aktif. Journal Kedokteran Brawijaya, 28(3), 213-216. https://doi.org/10.21776/ub.jkb.2015.028.03.9

Baars, J. B., \& Gage, N. M. (2010). Cognition, brain and consciousness (2nd ed.). Oxford United Kingdom: Elsevier Ltd. https://doi.org/10.1016/B978-0-12-375070-9.00001-2

Babamohamadi, H., Sotodehasl, N., Koenig, H. G., Jahani, C., \& Ghorbani, R. (2015). The effect of Holy Qur'an recitation on anxiety in hemodialysis patients: a randomized clinical trial. J Relig Health. 54, 1921-1930. https://doi.org/10.1007/s10943-014-9997-x

Bakheit, A. M. O., Shaw, S., Barret, L., Wood, J., Griffiths, S., Carrington, S., Searle, K., \& Kautsi, F. (2007). A prospective, randomized, parallel group, controlled study of the effect of intensity of speech and language therapy on early recovery from poststroke aphasia. Clinical Rehabilitation, 21, 885-894. https://doi.org/10.1177/0269215507078486

Bandura A. (1994). Self-efficacy in changing societies. Cambridge: New York: Cambridge University Press. https://doi.org/10.1017/CBO9780511527692

Bandura A. (2001). Social Cognitive Theory of Mass Communication. New York. Cambridge University Press. https://doi.org/10.1207/S1532785XMEP0303_03

Barrett, B., Marchand, L., Scheder, J., Appelbaum, D., Plane, M., \& Blus-tein, J. (2004). What comple-mentary and alternative medicine practitioners say about health and health care. The Annals of Family Medicine, 2, 253-259. https://doi.org/10.1370/afm.81

Bays, C. L. (2001). Older Adults Description of Hope After Stroke. Rehabilitation Nursing, Januari/Februari 2001. https://doi.org/10.1002/j.2048-7940.2001.tb02203.x

Bechir, F., Wajdi, M., Abir, B., Hamdi, J., Salem, A. A., \& Zohra, B. S. (2017). Effects of listening to Holy Qur'an recitation and physical training on dialysis efficacy, functional capacity, and psychosocial outcomes in elderly patients undergoing haemodialysis. Libyan Journal of Medicine, 12(1), 1372032. https://doi.org/10.1080/19932820.2017.1372032

Berthier, M. L. (2005). Post stroke aphasia: epidemiology, pathophysiology, and treatment. Drugs and Aging, 22(2), 163-82. https://doi.org/10.2165/00002512-200522020-00006

Bottiroli, S., Cavallini, E., \& Vecchi, T. (2008). Long-term Effects of Memory Training in the Elderly: A Longitudinal Study. Archives of Gerontology and Geriatrics, 47, 277-289. https://doi.org/10.1016/j.archger.2007.08.010

Boonen, E., Vervenne, H., Meersseman, P., Andrew, R., Mortier, L., Declercq, P. E., \& Berghe, G. V. D. (2013). 
Reduced Cortisol Metabolim During Critical Illnes. The New England Journal of Medicine, 368(16), 1477-1488. https://doi.org/10.1056/NEJMoa1214969

Bullain, S. S., Chiki, L. S., \& Stern, T. A. (2007). Aphasia : Associated disturbance in affect. Behaviour and cognition in the setting of speech and language difficulties. Psychomatics, 48, $259-264$. https://doi.org/10.1176/appi.psy.48.3.258

Burgess, P. W., Simons, J. S., Dumontheil, I., \& Gilbert, S. J. (2003). The gateway hypothesis of rostral prefrontal cortex (area 10) function. In Duncan, J., Philips, L., \& McLeod, P. (Eds.), Measuring the mind, speed, control and age (pp. 217-248). Oxford, United Kingdom: Oxford University Press. https://doi.org/10.1093/acprof:oso/9780198566427.003.0009

Caplan, D. (1987). Neurolinguistics and Linguistic Aphasiology. Melbourne: Cambridge University Press. https://doi.org/10.1017/CBO9780511620676

Cavallini, E., Pagnin, A., \& Vecchi, T. (2003). Aging and Everyday Memory: The Beneficial Effect of Memory Training. Arch Gerontol. Geriatr, 37, 241-257. https://doi.org/10.1016/S0167-4943(03)00063-3

Chang, M. Y., Chen, C. H., \& Huang, K. F. (2008). Effects of music therapy on psycholog- ical health of women during pregnancy. $J$ Clin Nurs., $17(19), \quad 2580-7 . \quad$ PubMed: 18298503. https://doi.org/10.1111/j.1365-2702.2007.02064.X

Chemerinski, E., \& Robinson, R. (2000). The Neuropsychiatry of Stroke Psychosomati. Journal, 41, 1 Januari Februari 2000. https://doi.org/10.1016/S0033-3182(00)71168-6

Cooke, M., Chaboyer, W., \& Hiratos, M. A. (2005). Music and its effect on anxiety in short waiting periods: a critical appraisal. Journal of Clinical Nursing, $145-155$. https://doi.org/10.1111/j.1365-2702.2004.01033.x

Dasgupta, A., \& dan Beard, V. A. (2007). Community Driven Development, Collective Action and Elite Capture in Indonesia. Development and Change, 38, 229-249. https://doi.org/10.1111/j.1467-7660.2007.00410.x

De Haan, R., Limburg, M., Van der Meulen, J. H. P., Jacobs, H. M., \& Aaronson, N. (1995). Quality of Life After Stroke: Impact of Stroke Type and Lesion Location. Stroke, 26, $402-408$. https://doi.org/10.1161/01.STR.26.3.402

Douiri, A., Rudd, A. G., \& Wolfe, C. D. (2013). Prevalence of poststroke cognitive impairment: South London stroke register 1995-2010. Stroke, 44, 138-145. https://doi.org/10.1161/STROKEAHA.112.670844

Dubuc, B. (2004). Broca's area, Wernicke's area and other language-processing areas in the brain. Retrieved from http://thebrain.mcgill.ca/flash/a/a_10/a_10_cr/a_cr_lan/a_10_cr_lan.html

Edmans, J. (2010). Occupational Therapy and Stroke. Blackwell Publishing: UK Engvig A., https://doi.org/10.1002/9781444323801

Eskandari, N., Keshavars, M., Ashayeri, H., Jahdi, F., \& Hosseini, A. F. (2012). Quran Recitation: Short-Term Effects \& Related Factors in Preterm Newborns. Res J Med Sci, 6(3), 148-153. https://doi.org/10.3923/rjmsci.2012.148.153

Fadda, G., \& Jirón, P. (1999). Quality Of Life And Gender: A Methodology For Urban Research. Environment and Urbanization journal of sagepub, 11, 261. https://doi.org/10.1630/095624799101285011

Farrell, C. (2004). Poststroke Depression in Elderly Patients. Journal of Dimens Critical Care Nursing, 23(O5), 264-269. https://doi.org/10.1097/00003465-200411000-00007

Fathilkamal, N., Aini, \& Elia. (2011). Salat and brainwave signal analysis. Jurnal Teknologi (Sains \& Kej.), 54, 181-192. Universiti Teknologi Malaysia. https://doi.org/10.11113/jt.v54.809

Fatoye, F. O. (2009). Depressive symptoms and associated factors following cerebrovascular accident among Nigerians. Journal of Mental Health, 18(3), 224-232. https://doi.org/10.1080/09638230701879094

Folkman, S., \& Lazarus, R. S. (1985). If It Changes It Must Be a Process: Study of Emotion and Coping During Three Stages of a College Examination. Journal of Personality and Social Psychology, 48(1), 150-170. https://doi.org/10.1037//0022-3514.48.1.150

Ghoge, H., Sharma, S., Sonawalla, S., \& Parikh, R. (2003). Cerebrovascular Diseases and Depression. Curr Psychiatry Rep, 5, 231-8. https://doi.org/10.1007/s11920-003-0048-7

Goldstein, A., Albert, M. J., Bushwell, C. D., Appel, L. J., Brass, L. M., Culebras, A., ... \& Sacco, R. L. (2006). 
Primary prevention of ischemic stroke. A guideline from the American Heart Association/American Stroke Association Stroke Council. Stroke, 37, 1583-1633. https://doi.org/10.1161/01.STR.0000223048.70103.F1

Hamilton, R. H., \& Leone, A. P. (1998). Cortical Plasticity Associated with Braille Learning. Trends in Cognitive Science, 2(5), 168-174. https://doi.org/10.1016/S1364-6613(98)01172-3

Hosseini, M., Salehi, A., Fallahi Khoshknab, M., Rokofian, A., \& Davidson, P. M. (2013). The effect of a preoperative spiritual/religious intervention on anxiety in Shia Muslim patients undergoing coronary artery bypass graft surgery: a randomized controlled trial. $J$ Holist Nurs. 31(3), 164-72. https://doi.org/10.1177/0898010113488242

Huang, C. Y., Hsu, M. C., Hsu, S. P., Cheng, P. C., Lin, S. F., \& Chuang, C. H. (2010). Mediating roles of social support on poststroke depression and quality of life in patients with ischemic stroke. J Clin Nurs., 19(19-20), 2671-2956. https://doi.org/10.1111/j.1365-2702.2010.03327.x

Hughes, J. W., Tomlinson, A., Blumenthal, J. A., Davidson, J., Sketch, M. H., \& Watkins, L. L. (2004). Social support and religiosity as coping strategies for anxiety in hospitalized cardiac patients. Ann Behav Med., 28(3). https://doi.org/10.1207/s15324796abm2803_6

Keizer, A. W., Verschoor, M., Verment, R. S., \& Hommel, B. (2009). The effect of Gamma enhancing Neurofeedback on the control of feature bindings and intelligence measures. International Journal of Psychophysiology. https://doi.org/10.1016/j.ijpsycho.2009.10.011

Kelly-Hayes, M., Beiser, A., Kase, C. S., Scarramucci, A., DAgustino, R. B., \& Wolf, P. A. (2003). The influence of gender and age on disability following ischemic stroke, the framingham study. Journal Stroke cerebrovascular. 12, 119-126. https://doi.org/10.1016/S1052-3057(03)00042-9

Kim, J. S. (2016). Post-stroke Mood and Emotional Disturbances: Pharmacological Therapy Based on Mechanisms. Journal of stroke. 18(3), 244-255. https://doi.org/10.5853/jos.2016.01144

Knyazev, G., G. (2011). EEG delta oscillations as a correlate of basic homeostatic and motivational processes. Neuroscience and Biobehavioural Reviews, (36), 677-695. https://doi.org/10.1016/j.neubiorev.2011.10.002

Kral, A., Hartmann, R., Tillein, J., Heid, S., \& Klinke, R. (2002). Hearing After Congenital Deafness: Central Auditory Plasticity and Sensory Deprivation. Cerebral Cortex, 12, 797-807. https://doi.org/10.1093/cercor/12.8.797

Kusuma, Y., Venketasubramanian, N., Kiemas, L. S., \& Misbach, J. (2009). Burden of Stroke In Indonesia. International Journal of Stroke, 4, 379-380. https://doi.org/10.1111/j.1747-4949.2009.00326.x

Lawes, C. M. M., Bennett, D. A., Feigin, V. L. et al. (2004). Blood Pressure and stroke. An overview of published reviews. Stroke, 35, 1024-1033. https://doi.org/10.1161/01.STR.0000126208.14181.DD

Lee, A. C. K., Tang, S. W., Tsoi, T. H., Fong, D. Y. K., \& Yu, G. K. K. (2009). Predictors of poststroke of life in older chinese adults. Journal of Advanced Nursing. 65(3), 554-564. https://doi.org/10.1111/j.1365-2648.2008.04918.x

Linden, T., Samuelsson, H., Skoog, I., \& Bloomstrand, C. (2005). Visual Neglect and Cognitive Impairment in Elderly Patients Late After Stroke. Acta Neurol Scand, 111, 163-168. https://doi.org/10.1111/j.1600-0404.2005.00391.x

Lin, J. H., Lin, R. T., Tai, C. T., Hsieh, C. L., Hsiao, S. F., \& Liu, C. K. (2003). Prediction of poststroke dementia. Neurology, 61, 343-348. https://doi.org/10.1212/01.WNL.0000078891.27052.10

Lopez, J. S., \& Snyder, R. C. (2003). Positive Psychological Assessment: A Handbook of Models and Measures. Washington, DC: American Psychological Association. https://doi.org/10.1037/10612-000

Mahjoob, M., Nejati, J., Hosseini, A., \& Bakhshani, N. M. (2016). The effect of Holy Quran voice on mental health. J Relig Health, 55, 38-44. https://doi.org/10.1007/s10943-014-9821-7

Mayo, K. R. (2009). Support from neurobiology for spiritual techniques for anxiety: a brief review. J Health Care Chaplain. https://doi.org/10.1080/08854720903451055

McDonnell, M. N., Bryan, J., Smith, A. E., \& Esterman. A. J. (2011). Assessing Cognitive Impairment Following Stroke. Journal of Clinical and Experimental Neuropsychology, 33. https://doi.org/10.1080/13803395.2011.575769

Miller, L. M., Gall, T. L., \& Corbeil, L. (2011). The experience of prayer with a sacred object within the context of significant life stress. Journal of Spirituality in mental Health, 13, 247-271. 
https://doi.org/10.1080/19349637.2011.616101

Mohamed, C. R., Nelson, K., Wood, P., \& Moss, C. (2014). Issues post-stroke for Muslim people inmaintaining the practice of salat (prayer): A qualitative study. Collegian, 14, 22. https://doi.org/10.1016/j.colegn.2014.01.001

Mojgan, M., Fahimeh, S. S., Sakineh, M.-A.-C., \& Batoul, J. (2016). Effect of Vocalization of the Holy Quran With and Without Translation on Pregnancy Outcomes: A Randomized Clinical Trial. Iran Red crescent Med J., 18(9), e35421. https://doi.org/10.5812/ircmj.35421

Moller, A. R. (2006). Neural Plasticity and Disorders of The Nervous System. UK: Cambridge University Press. https://doi.org/10.1017/CBO9780511616228

Murphy, T. H., \& Corbett. (2009). Plasticity During Stroke Recovery: From Synapse to Behavior. Neuroscience, 10, 861-872. https://doi.org/10.1038/nrn2735

Nakao S. et al. (2010). Relationship between Barthel Index Scores during the Acute Phase or Rehabilitation and Subsequent ADL in Stroke Patients. The Journal of Medical Investigation, 57(2), 81-8. https://doi.org/10.2152/jmi.57.81

Nasiri, M., Naboureh, A., \& Fayazi, S. (2017). The Effect of an Islamic Praise (Zikr) on Postoperative Anxiety of Patients Undergoing Coronary Artery Bypasses Graft Surgery: A Randomized Clinical Trial on Iranian Shia Muslims. Res Cardiovasc Med., 6(3), e41388. https://doi.org/10.5812/cardiovascmed.41388

Nichols-Larsen, D. S., Clark, P. C., Zeringue, A., Greenspan, A., \& Blanton, S. (2005). Factors influencing stroke survivors' quality of life during subacute recovery. Stroke, 5, 36(7), 1480-1484. https://doi.org/10.1161/01.STR.0000170706.13595.4f

Nurdin, E. A. (2015). Pendekatan Psikoneuroimunologi. Andalas Journal of Health, 34, 90-101. https://doi.org/10.22338/mka.v34.i2.p90-101.2010

Olesen, P. J., Westerberg, H., \& Klingberg, T. (2003). Increased Prefrontal and Parietal Activity After Training of working Memory. Nature Neuroscience, 7(1), 75-79. https://doi.org/10.1038/nn1165

Pedelty, L., \& Gorelick, P. B. (2009). Update on Management of Hypertension to Prevent Stroke. Current Treatment Options in Neurology, 8, 486-495. https://doi.org/10.1007/s11940-006-0038-2

Pendlebury, S. T., \& Rothwell, P. M. (2009). Prevalence, incidence, and factors associated with pre-stroke and post-stroke dementia: A systematic review and meta-analysis. Lancet Neurol, 8, 1006-1018. https://doi.org/10.1016/S1474-4422(09)70236-4

Pickard, S. A., Neary, M. P., \& Cella, D. (2007). Health and Quality of Life Outcomes Open Access Research Estimation of minimally important differences in EQ-5D utility and VAS scores in cancer Center for Pharmacoeconomic Research, Department of Pharmacy Practice, College of Pharma. Health and Quality of Life Outcomes, 5, 70. https://doi.org/10.1186/1477-7525-5-70

Pouralkhas, S., Rajabi, S., \& Pishgar, A. (2012). Investigating the Rate of Qur'an Reciting by Persian Language and Literature Students in Comparison with Students of Other Fields and Its Effect on Depression, Anxiety and Stress. Journal of Language Teaching and Research, 3(5), 1004-1008. https://doi.org/10.4304/jltr.3.5.1004-1008

Rasyid, A. L., \& Lyna, S. (2007). Comprehensive Stroke Management Stroke Unit. Jakarta: FKU Publisher Hall.

Roger, V. et al. (2017). Heart Disease and Stroke Statistics-2017 Update: A Report From the American Heart Association. Circulation, 135(10), 146-603. https://doi.org/10.1161/CIR.0000000000000491

Russo, T., Felzani, G., \& Marini, C. (2011). Stroke in the very old: A systematic review of studies on incidence, outcome, and resource use. J Aging Res, 2011, 108785. https://doi.org/10.4061/2011/108785

Ryan, R., Lynch, M.F., Vansteenkiste, M., \& Deci, E. L. (2011). Motivation and autonomy in counseling, psychotherpy, and behavior change: A look at theory and practice. The Counseling Psychologist, 39. https://doi.org/10.1177/0011000009359313

Salisbury, D. F., McCarley, R. W., Nakamura, M., \& Shenton, M. E. (2008). Combining ERP and structural MRI information in first episode schizophrenia and bipolar disorder. Official Journal of the EEG and Clinical Neuroscience Society, 39, 57-60. https://doi.org/10.1177/155005940803900206

Salter, K., Jutai, J., Foley, N., Hellings, C., \& Teasell, R. (2006). Identification of aphasia poststroke : A review screening assesment tools. Brain injury, 20(6), 559-568. https://doi.org/10.1080/02699050600744087 
Sholeh, M. (2012). Tahajud Prayer Therapy Cures Various Diseases. Jakarta: PT. Mizan Publika.

Sit, J. W. H., Wong, T. K. S., Clinton, M., Li, L. S. W., \& Fong, Y. M . (2004). Stroke care in the home : the impact of social support on the general health of family care givers. Journal of Clinical Nursing. https://doi.org/10.1111/j.1365-2702.2004.00943.x

Sooki, Z., Sharifi, Kh., \& Tagharobi, Z. (2011). Role of Qur'an Recitation in Mental Health of The Elderly. Quarterly of Qur'an \& Medicine, 1(1), 17-23. https://doi.org/10.5812/nms.7915

Stanley, M. A., \& Maddux, J. E. (1986). Cognitive Processes in Health Enhancement: Investigation of a Combined Protection Motivation and Self-Efficacy Model. Basic and Applied Social Psychology, 7(2). https://doi.org/10.1207/s15324834basp0702_2

Stephen S., Kenny, R. A., Rowan, E., Kalaria, R. N., Path, F. R. C., Bradbury, M., .. \& Ballard, C. V. (2005). Association Between Mild Cognitive Impairment and Impaired Activities of Daily Living in Older Stroke Survivors Without Dementia. $J$ Am Geriatr Soc, 53, 103-107. https://doi.org/10.1111/j.1532-5415.2005.53019.x

Steptoe, A., \& Brydon, L. (2005). Psychoneuroimmunology and coronary artery disease. In: K. Vedhara, \& M. Irwin (Eds.). Human Psychoneuroimmunology. Oxford: Oxford University Press. https://doi.org/10.1093/med:psych/9780198568841.003.0005

Storor, D. L., \& Byrne, G. J. A. (2006). Premorbid personality and depression following stroke. Australia. https://doi.org/10.1017/S1041610206003188

Sulaeman S. (2013). Model Pemberdayaan Masyarakat Bidang Kesehatan Studi Program Desa Siaga. Surakarta: Sebelas Maret University Press. https://doi.org/10.21109/kesmas.v7i4.54

Tang,Y. Y., \& Chen, S. P. (2002). Health Promotion Behaviours In Chinnese Family Caregivers Of Patiens with Stroke. Health Promotion International, 17(4). https://doi.org/10.1093/heapro/17.4.329

Tartaro, J., Luecken, L. J., \& Gunn, H. E. (2005). Exploring heart and soul: Effects of Religiosity/Spirituality and Gender on Blood Pressure and Cortisol Stress Responses. J Health Psychol, 10(6), 753-66. https://doi.org/10.1177/1359105305057311

Thorndike, E. (1932). The Fundamentals of Learning. New York: Teachers College Press. https://doi.org/10.1037/10976-000

Toole, J.F., R. Bhadelia, R.D. Williamson \& R. Veltkamp. (2004). Progressive Cognitive Impairment After Stroke. Journal of Stroke and Cerebrovascular Diseases, Vol. 13 (3): 99-103. https://doi.org/10.1016/j.jstrokecerebrovasdis.2004.03.005

Tumiran, M. A., Mohamad, S. P., Saat, R. M., Yusoff, M. Y. Z. M., Rahman, N. N. A., \& Adli, D. S. H. (2013). Addressing sleep disorder of autistic children with Qur'anic sound therapy. Health, 5(08), 73-79. https://doi.org/10.4236/health.2013.58A2011

Turin, T. C., Kita, Y., Rumana, N., Takashima, N., Ichikawa, M., Sugihara, H., ... \& Ueshima, H. (2009). The Time Interval Between Stroke Onset and Hospitalization and Its Related Factor. Neuroepidemiology, 33, 240-246. https://doi.org/10.1159/000229778

Vakhnina N.V., Nikitina, L. Y., Parfenov, V. A., \& Yakhno, N. N. (2009). Post Stroke Cognitive Impairment. Neuroscience and Behavioral Physiology, 39(8), 719-724. https://doi.org/10.1007/s11055-009-9198-3

Valentijn, S. A. M., Hooren, S. A. H. V., Bosma, S., Touw, D. M., Jolles, J., Boxtel, M. P. J. V., \& Ponds, R. W. H. M. (2005). The Effect of Two Types of Memory Training on Subjective and Objective Memory Performance in Healthy Individuals Aged 55 Years and Older: A Randomized Controlled Trial. Patient Education and Counseling, 57, 106-114. https://doi.org/10.1016/j.pec.2004.05.002

Wade, D. T., Langton-Hewer, R., Wood, V. A., Skilbeck, C. E., \& Ismail, H. M. (1983). The Hemiplegic Arm after Stroke: Measurement and Recovery. From the Stroke Recovery Research Unit, Department of Neurology, Frenchay Hospital, Bristol, UK. https://doi.org/10.1136/jnnp.46.6.521

Wahl, A. K., Rustøen, T., Hanestad, B. R., Lerdal, A., \& Moum, T. (2004). Quality of life in the general Norwegian population, measured by the Quality of Life Scale (QOLS-N). Journal Faculty of Nursing, Oslo University College, Norway. https://doi.org/10.1023/B:QURE.0000025583.28948.5b

Ware, J. E. Jr., \& Sherbourne, C. D. (1992). The MOS 36-item short-form health survey (SF-36). I. Conceptual framework and item selection. Med Care, 30, 473-483. https://doi.org/10.1097/00005650-199206000-00002 
World Health Organization (WHO). (2014). Environmental Health. Retrieved June 23, 2017, from http://www.who.int.

WHO Package of essential noncommunicable (PEN) disease interventions for primary health care in low-resource settings. Geneva: World Health Organization. (2016). Retrieved from http://www.who.int/nmh/publications/essential_ncd_interventions_lr_settings.pdf

Whynes, D. K. (2013). Does the correspondence between EQ-5D health state description and VAS score vary by medical condition? Whynes Health and Quality of Life Outcomes, 11, 155. https://doi.org/10.1186/1477-7525-11-155

Willis, S. L., Tennstedt, S. L., Marsiske, M., Ball, K., Elias, J., Koepke, K. M., .. \& \& Wright, E. (2006). Long-Term Effects of Cognitive Training on Everyday Functional Outcomes in Older Adults. JAMA, 296(23), 2805-2814. https://doi.org/10.1001/jama.296.23.2805

Wills, T. A., \& Cohen, S. (1985). Stress, Social Support an the Buffering Hypothesis. Psychological Bulletin. 98(2), 310-357. https://doi.org/10.1037//0033-2909.98.2.310

Yasui, Y. (2009). A brainwave signal measurement and data processing technique for daily life applications. $J$ Physiol Antropol, 28(3), 145-150. https://doi.org/10.2114/jpa2.28.145

Zulkurnaini, N. A., Kadir, R. S. S. A., Murat, Z. H., \& Isa, R. M. (2012). The comparison between listening to al-Quran and listening to classical music on the brainwave signal for the alpha band. Paper presented at the Third International Conference on Intelligent Systems, Modelling and Simulation (ISMS), Malaysia: Kota Kinabalu. https://doi.org/10.1109/ISMS.2012.60

\section{Copyrights}

Copyright for this article is retained by the author(s), with first publication rights granted to the journal.

This is an open-access article distributed under the terms and conditions of the Creative Commons Attribution license (http://creativecommons.org/licenses/by/4.0/). 